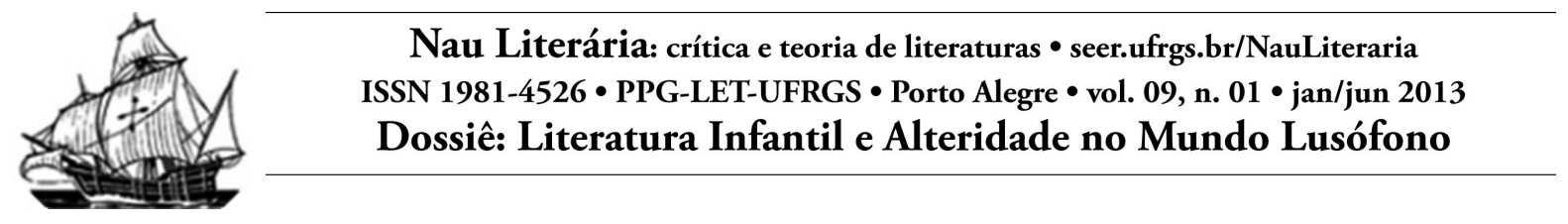

\title{
Os romances infantojuvenis de António Mota
}

\author{
Carlos Manuel Nogueira \\ Geice Peres Nunes
}

\begin{abstract}
Resumo: Neste ensaio, pretende-se estudar os temas e o estilo dos romances para a infância e a juventude de António Mota. Nos livros do autor de Pedro Alecrim, a vida aparece como um permanente e plural desafio, a que cada personagem, a partir da sua individualidade e liberdade, responde na condição de ator que se move num complexo quadro familiar e cultural. A dualidade e a tensão interna das personagens atravessam invariavelmente as narrativas, mas impõe-se sempre uma visão apoteótica da vida. $\mathrm{O}$ enunciador, gerindo e respeitando as vozes que dizem a proposição irrefutável de que a vida é difícil e injusta, contrapõe às suas próprias dúvidas e medos uma espécie de utopia: a vida só vale a pena se for a constante invenção de um ideal. A uma desistência ou a um abatimento seguem-se uma reação, um movimento de energia e uma (re)construção.
\end{abstract}

Palavras-chave: romance juvenil; António Mota; Portugal.

\begin{abstract}
This essay studies the themes and style of António Mota' juvenile novels. In these books, life appears as a permanent and plural challenge, to which every character, using his individuality and freedom, responds like an actor who moves in a familiar and cultural complex context. The duality and the characters' inner tension go through the narratives but there is always a optimistic vision of life. The narrator, managing and respecting the voices that say the irrefutable proposition that life is hard and unfair, opposes to his own doubts and fears a kind of utopia: life is only worthwhile if it is the constant invention of an ideal. Desistance and low spirits are followed by a reaction, a movement of energy and a (re)construction.
\end{abstract}

Keywords: juvenile romance; António Mota; Portugal.

A obra literária de António Mota, destinada ao público infantojuvenil, constituída por cerca de quarenta títulos, exige, pela qualidade e quantidade, um estudo de conjunto que proceda a uma análise discriminada de cada livro e a uma abordagem comparatista que nos elucide sobre os aspectos essenciais da 
temática e do estilo, sua evolução ou superação. O que aqui apresentamos é apenas a primeira fase do trabalho que estamos a dedicar aos livros do autor nascido em 1957 em Baião (o concelho mais interior do distrito do Porto, em Portugal). Centrar-nos-emos por ora nos romances que têm como destinatários privilegiados os pré-adolescentes e os adolescentes.

O contexto em que a maioria dos romances de António Mota se inscreve é o da crise social e mental das classes mais desfavorecidas do Norte rural de Portugal, do êxodo em massa do campo e suas consequências imediatas: desertificação acelerada e alterações profundas e dramáticas na identidade quer dos que partem quer dos que ficam. Na carta que Jorge Ribeiro dos Santos escreve a Adrianinho, "um velho diferente de todos os velhos do meu lugar: não há moço que não goste dele" (MOTA, 1998, p. 13), lê-se: “Tenho saudades de Louredo. Tenho saudades de si. A minha mãe volta e meia anda a chorar baixinho, tentando esconder as lágrimas. Diz ela: - Filho, digam lá as maravilhas que disserem das outras, mas a nossa terra é sempre a nossa terra" (MOTA, 1998, p. 123).

Cada novo romance desse autor é a expressão de um mundo em conflito, cujas implicações materiais e psicológicas na paisagem rural portuguesa são enunciadas sinteticamente pela narradora de Os Heróis do $6{ }^{\circ} \mathrm{F}$ :

\begin{abstract}
A Barroca, não sei se já o disse, é uma aldeia serrana e pequenina. Aqui cada vez há mais casas desabitadas, muitos velhotes e pouca gente nova. Só em Agosto é que a minha aldeia fica cheia de gente e de carros com matrículas luxemburguesas, francesas, alemãs e suíças. Só nessa altura do ano é que o senhor Abel liga a máquina de café todos os dias logo de manhãzinha, e compra caixas de camarão congelado. Acabado o Agosto, volta o silêncio, a pasmaceira, e a máquina de café do senhor Abel só é ligada aos fins-de-semana. (MOTA, 1999d, p. 29-30)
\end{abstract}

Ao tema central da desagregação das práticas e do imaginário do mundo rural ligam-se outros temas e motivos, cujo tratamento original explica o sucesso desses romances, publicados entre 1986 e 2005, junto dos jovens leitores 
portugueses: a escola (sobretudo a das décadas de 50 a 70, mas também a nova escola da década de 90), a conjugação entre o trabalho no campo e a vida escolar, o abandono demasiado precoce da escola e a entrada no mundo do trabalho, a família, a figura e o estatuto da mulher, do homem e da criança ou do pré-adolescente e do jovem adulto, o amor e a sexualidade, o desemprego, a fome, a miséria, a superstição, a ignorância, o envelhecimento e a morte, a procura de um lugar numa sociedade excessivamente estratificada e injusta.

$\mathrm{O}$ discurso de primeira pessoa, organizado por um protagonista que frequenta ou frequentou o $4 .^{\circ}$, o $5 .^{\circ}$ ou o $6 .^{\circ}$ anos de escolaridade, aproxima os leitores do jovem herói ou dos jovens heróis (e de personagens secundárias que muito contribuem para o "efeito de verdade" destes relatos, como escreveu Matilde Rosa Araújo no prefácio à primeira edição de O Rapaz de Louredo). Essa coincidência de perspectivas vem do que é afinal a essência de muitos dos temas e motivos focados: o interesse do sujeito por si próprio e pelo outro enquanto objetos de amor e de sexualidade, a vida escolar e a vida em família, o diálogo com os adultos e a integração no mundo do trabalho.

Mas a atualidade de um universo ficcional que radica no que um leitor apressado poderá considerar anacrônico para os nossos (pré-)adolescentes se deve também ao modo como todas essas questões sensíveis são apresentadas em termos de representação narrativa e em termos de linguagem e de estilo: narração ágil, não raro encaixando níveis narrativos, que se abre sempre a novos núcleos de sentido, a momentos de descrição e sobretudo a diálogos, cujos meios de expressão são a um tempo sintéticos e ricos em poder de evocação e em convites à reflexão. Ou seja: rapidamente o leitor de António Mota interiorizará que a literatura é memória e construção do futuro com conhecimento do passado.

A escrita de António Mota desenvolve um sentido de naturalidade que decorre da articulação entre a verossimilhança dos temas e da intriga, a nitidez 
da frase e a autenticidade do léxico. A abundância de provérbios, modismos populares, regionalismos dialetais ou socioletais, coloquialismos, expressões idiomáticas, plebeísmos e até calão contribuem muito para isso: "Ceguinho fosse eu” (MOTA, 1999d, p. 71); "Oxalá que a roda não comece a andar para trás" (MOTA, 1999d, p. 127); "E dormíamos sonos de pedra" (MOTA, 2005, p. 145); “- Tenho-as aqui sachadas", responde a mãe do narrador-protagonista à filha, que "uma noite começou a dizer que lhe apetecia comer febras de porco" (MOTA, 2005, p. 204-205); ou "o pai continua caladinho como um rato" (MOTA, 2005, p. 208), entre muitas outras "formas breves" ou mínimas. Tratase de fórmulas, como se percebe por este brevíssimo levantamento, a que ao núcleo formal invariante (não raro mais evocado que verdadeiramente conhecido ou fixado) acrescem variações ditadas pelo contexto situacional e de interação verbal.

É um modo de dizer o mundo por meio de uma linguagem que o grupo edifica; mas uma linguagem que também molda a comunidade, um dizer breve cujos níveis de sentido não podem ser avaliados em termos de ética ou de maldade. Esse dizer é um elemento vital da natureza humana, sempre matizada de imprevisto, ousadia, imaginação e engenho crítico: “- Se o inocente morrer, que te caiam em cima do corpo todas as maleitas do mundo, e que a tua alma nunca tenha descanso" (MOTA, 1999e, p. 71). Tal microtexto, que organiza o caos de palavras e sentimentos do enunciador, é um modelo perfeito de um gênero praticamente ignorado pelos estudiosos portugueses: a praga, que nasce tanto em momentos de crise individual como em períodos de crise de valores morais, éticos e religiosos. Um gênero que já definimos como

palavra-sátira que, enquanto corpo estético e pragmático, total na sua brevidade, racional na sua voragem aparentemente só movida por uma vil e descontrolada irracionalidade, acontece com o fim de remir o enunciador, lançando-o, altivo e vitorioso, pelo menos no momento da proferição, sobre um oponente (NOGUEIRA, 2007, p. 129). 
Aquela "praga", que conserva todos os elementos literários e antropológicos que fazem a especificidade do gênero, só na superfície textual não convoca personagens mágico-sagradas que acrescentem força ao poder psíquico do sujeito e à energia das palavras-rito por ele pronunciadas. O protocolo de respeito e obediência exigido no contato com essas entidades divinas não pode se concretizar canonicamente por motivos óbvios: a dicção e a eficácia perlocutória que se espera do texto não são compatíveis com a mensagem de Cristo. Mas a nomeação do divino, eficaz na intensificação do tom injuntivo e autoritário do texto, é desencadeada pelo enunciador no espaço do não dito ou aludido: o adjetivo substantivado "inocente" promove, sem necessidade de mais palavras, essa nomeação.

Cada livro do autor de A Casa das Bengalas é então uma longa fala, estilizada e sem afetação, precisamente porque existe essa convergência entre a expressividade temática e a riqueza estilística. A arquitetura rítmico-melódica da oralidade literária de António Mota é regida por uma infraestrutura frásica de extensão média e curta que seduz pela fluência e musicalidade e pelas propriedades cinematográficas.

O que coordena a justaposição dos quadros, a sucessão de planos visuais que se constituem cinematograficamente, são os sentidos da memória e da vista. Esse olhar dinâmico, que promove o prazer da expectativa, garante-nos certa compreensão da neurofisiologia da escrita de António Mota: olhar sobre quadros de imagens em movimento, raciocínio com emoções (Aristóteles), energia mental que progride de um ponto para outro. O processo narrativo desenvolve-se diante dos olhos do leitor-espectador, a quem é comunicada a interiorização de um real pluridimensional cujo conteúdo é extraído da sua natureza cinética; e a quem, portanto, nos processos de descrição de espaços e personagens e de 
narração de acontecimentos, é dada a ver uma série de cenas ou episódios encadeados ou justapostos.

\section{A sintagmática dos romances de António Mota}

Pardinhas é um livro que nos dá, no segundo nível narrativo, uma panorâmica do Portugal rural, analfabeto e austero dos tempos do salazarismo. O núcleo do romance é constituído pela narração de episódios marcantes da vida do avô, que, como se anuncia no final da primeira parte, assumirá a seguir a enunciação: "O avô fechou os olhos, pôs uma mão na testa, e começou a falar" (MOTA, 2005, p. 38). Nesse e noutros romances de António Mota recupera-se, em tom solene, a figura dos mais velhos como contadores de histórias reais que trazem ao mundo a eternidade do passado: "Em Pardinhas toda a gente tinha uma alcunha, muitas vezes herdada dos bisavós. Eu pertencia à família dos bispos. O apelido vinha do meu avô, pai do meu pai” (MOTA, 2005, p. 41).

A viagem da família à aldeia do avô é a situação diegética que serve de pretexto ao nível narrativo nuclear: "Passámos por Valongo, Paredes, Penafiel. Em Amarante estacionámos o carro perto da Ponte de S. Gonçalo. Nas águas do Tâmega nadavam patos" (MOTA, 2005, p. 31). Mas convém sublinhar que esse primeiro nível narrativo, apesar de subsidiário do segundo, coloca questões muito relevantes para o crescimento interior dos mais novos e para a comunidade como um todo: o envelhecimento, a doença, a solidão, a aproximação da morte, a inadaptação dos mais velhos à vida na cidade. Cada vez mais a sociedade moderna protege as suas crianças e os adolescentes de tudo o que implica sofrimento imediato. António Mota sabe que esse silêncio pode trazer a diminuição da autonomia da criança e do grupo e, por isso, aborda essas realidades. Ao fazê-lo, está a contrariar uma opinião muito divulgada: a de que há temas que não devem ser tratados na literatura infantojuvenil. Os leitores, 
contudo, interessados no passado do seu país e em compreender o mundo, dão razão a António Mota e leem-no.

Pardinhas contém e confirma o que é próprio do autor de Pedro Alecrim e de O Rapaz de Louredo: a construção de uma narrativa que, enquanto história de uma personagem ou família, é uma saga. Por exemplo: a história de Jorge Ribeiro dos Santos, o protagonista de O Rapaz de Louredo, que sai da sua pequena aldeia para se fixar definitivamente na cidade, onde o seu pai encontra trabalho, não é só uma síntese do percurso de várias gerações de portugueses; é também uma alegoria da vida humana, da sua complexidade e dos seus imprevistos.

A figura do adulto mais velho, em especial a avó e o avô, é nessa obra revalorizada como corpo de afetos e de conhecimentos. Da sua presença na história vem a lição de que a vida é breve e cedo começa a fazer concessões à doença, ao envelhecimento e à desistência psicossomática. $\mathrm{O}$ tratamento dessas temáticas, recorrentes na escrita de António Mota, não incorre no melodramático nem no apontamento meramente alusivo. O olhar sobre a fragilidade física do humano desdobra-se em soluções diegéticas que humanizam a decadência e a morte, sem, contudo, simplificarem o problema. Por isso é que, n'A Casa das Bengalas, privilegia-se o episódio do internamento do avô num Hospital e, n'O Rapaz de Louredo, releva-se a situação de Adrianinho, que vive entrevado'; e também por isso é que o narrador-protagonista de A Terra do Anjo Azul começa a conviver com a morte de Chico da Juliana, mestre na arte de esculpir a pedra ${ }^{2}$,

\footnotetext{
1 "O Adrianinho fala muito baixo, e não pode andar. A minha mãe contou-me que há muitos anos ele acamara com uma grave doença, e depois ficou assim, sem poder mexer as pernas. A partir dessa data nunca mais saiu de casa - e as muletas que um dia os vizinhos the ofereceram, juntando o dinheiro muito em segredo, nunca foram estreadas" (MOTA, 1998, p. 13-14).

2 "Nessa altura já eu tinha descoberto que o Chico da Juliana era um grande artista. Espalhadas pelo seu reino cercado por um muro tão alto, havia muitas esculturas de granito. Havia um cão parecidíssimo com o velho Mondego, que passava o tempo a dormitar na cozinha, deitado sobre uma manta velha e quase desfeita poisada num canto do preguiceiro; havia uma cabra com um úbere imenso, que roçava o chão; a cabeça de um cavalo que parecia rir-se, colocada junto de uma pequena laranjeira; e também havia um belo mocho guardado na sala, em cima da mesa" (MOTA, 2002, p. 6970).
} 
a partir do momento em que este lhe dirige uma pergunta muito incômoda (notese a perífrase e, simultaneamente, o eufemismo): “- Quando eu fechar os olhos, levas o anjo para a minha campa?" (MOTA, 2002, p. 71).

A mensagem que sobressai, mesmo nas narrativas em que a morte constitui um motivo aparentemente secundário, é a de que a cada um compete edificar o seu próprio destino, recusando ser objeto de fatalidade. $\mathrm{Na}$ bipolaridade em que se estruturam essas obras, a doença e a morte surgem como acontecimentos de perda irreversível, mas também de enriquecimento da memória individual e coletiva que a ficcionalização literária converte em memória elevada e eterna. O desaparecimento do criador do "anjo de pedra" (MOTA, 2002, p. 72), o velho Chico da Juliana, converter-se-á em presença ativa na memória do jovem Manuel.

A coloquialidade apoia-se na técnica da propriedade sintática: os constituintes frásicos unem-se com naturalidade, exatamente como na linguagem mais cotidiana. A isso acresce uma combinação de procedimentos de elaboração do tempo pelo discurso narrativo. A cena dialogada, enquanto ato de enunciação em que o tempo do discurso apresenta uma duração semelhante a do tempo da história, traz à leitura um efeito de verossimilhança imprescindível para a configuração ontológica desses universos ficcionais: lugares em que o leitor, por meio das personagens, contempla e vive a complexidade da sua natureza, desdobrando-se no outro, distanciando-se de si próprio ou objetivando a sua condição; lugares, por conseguinte, em que, autoconsciente e livre, lê e reescreve as suas palavras e as dos outros.

Nos universos narrativos de António Mota não há esboços de acontecimentos, meras perspectivas fugazes do passado, mas verdadeiras cenas a que se imprimem o máximo de intensidade simbólica e o máximo de expressividade imagética. Regra geral, na sintagmática narrativa não existem excrescências de qualquer tipo que atrasem o desenvolvimento equilibrado da 
ação. Os momentos descritivos, que nunca se desligam do olhar e pensamento do narrador-personagem sobre algum aspecto importante da diegese, inscrevemse sempre estreitamente na temporalidade da história. Essa inscrição de passagens descritivas em andamentos narrativos concretiza-se, aliás, em frases curtas, segmentos frásicos ou termos descritivos que têm como função imediata dinamizar os eventos narrados.

A própria temporalidade psicológica do sonho constitui uma história dentro da história que impulsiona o devir da personagem. $\mathrm{O}$ universo onírico não se reduz a um simulacro de vida: realidade em movimento, o sonho é uma atividade intensa, cerebral e acentuadamente física, não uma simples interiorização estática. Em António Mota, a representação desse mundo assenta no postulado de que as leis da vida e as leis do sonho se interpenetram; nesse caso, a lei da libido estabelece um vínculo direto entre o real do sonho e o real empírico:

E via mulheres, que surgiam como doninhas espantadas, por entre arvoredos cerrados. Aflito, sem saber o que fazer, com os pés colados na terra, com o sexo desperto e uma vontade enorme de me aproximar, não me decidia. Depois, por detrás desse matagal mais florido que as terras em Maio, surgiam bichos estranhos, de enormes bocas vermelhas, onde cresciam dentes finos como sovelas. Tinham rabos compridos e gelatinosos, que, só de vê-los, causavam náuseas. Roçando os ventres bojudos, silenciosos e repelentes, vinham ao meu encontro. E deixavam a descoberto um sulco na terra, onde brilhavam pedaços de ouro. (MOTA, 2005, p. 168)

A conclusão da sequência confirma o modo de funcionamento do sonho, em cuja textualização se torna evidente a ambiguidade das fronteiras entre o narrativo e o descritivo (GENETTE, s.d., p. 99): "Depois vinha meu pai, tão seco como um galho de árvore no Inverno. Derreava-se, apanhava o ouro, e ria muito. E eu acordava, a transpirar" (MOTA, 2005, p. 168-169).

O discurso iterativo (conta-se uma vez o que aconteceu várias vezes de modo idêntico) não tem apenas como função concretizar a economia da narrativa; é, nesta obra, técnica, consolidada pelo recurso à focalização interna, 
que destaca a ritualização que estrutura a vida, os ciclos em que as personagens se expandem, comprimem, negam ou revelam:

\begin{abstract}
Adoro trovoadas. Quando vejo os raios a ziguezaguear no céu escurecido, e ouço os trovões a seguir, sinto-me pequenina, pequenina. Minha mãe fica apavorada. Corre para dentro de casa, fecha as portas e janelas com estrondo, à bruta, desliga o televisor, o frigorífico e a arca congeladora, e reza de olhos fechados (MOTA, 1999d, p. 117-18).
\end{abstract}

A frequência muito assinalável com que o iterativo entra na sintagmática predominantemente singulativa (conta-se uma vez o que aconteceu uma vez) relaciona-se com a importância atribuída nessas narrativas à representação do fluxo inesgotável da consciência reflexiva do narrador ou de uma personagem (consciência integrada indelevelmente no narrado): "De vez em quando ficava muito calado, não tinha o apetite devorador, enfiava-se no barraco e falava com a passarada" (MOTA, 2005, p. 126).

Os lugares da memória são, em António Mota, eixos dinâmicos de imagens e pensamentos. No livro Os Heróis do $6 .^{\circ} \mathrm{F}$, o registro iterativo verifica-se logo na cena inicial (tal como em A Terra do Anjo Azul), não necessariamente por ordenar toda a composição do narrado, mas porque a sua colocação a abrir a história permitirá compreender melhor a interioridade e os comportamentos da narradora e da sua mãe:

- Lembras-te dele, Manuela?

Minha mãe costuma fazer essa pergunta quando me penteia devagarinho os cabelos compridos, pretos e lisos que me dão até meio das costas. E eu respondo, às vezes com impaciência:

- Sim! Estou farta de saber o que acontece logo de seguida: fica com a escova no ar, esquecida dos meus cabelos, da minha trança. Pouco depois deixa soltar um breve suspiro. (MOTA, 1999d, p. 5)

O iterativo não se subordina, portanto, ao singulativo (como ocorre na maioria das histórias da tradição oral). Os dois tipos de discurso convivem porque a voz que perspectiva o texto não quer reduzir a evocação de 
personagens e acontecimentos a um número finito de frases linearmente encadeadas. A lei da iteração é a lei da vida, marcada, deliberadamente ou não, por repetições, rotinas, obsessões, períodos.

A vida como poema é uma construção que, muitas vezes, se atribui à criança. António Mota concretiza essa poética em breves apontamentos descritivos, apoiados não raro pela comparação, sempre expressiva, como em "meu pai, tão seco como um galho de árvore no Inverno" ou "como doninhas espantadas" (MOTA, 1999d, p. 168), ou em andamentos que não excedem uma frase ou um parágrafo de uma ou duas frases. Esse é um momento particularmente sugestivo de introspecção e descrição ao mesmo tempo poética e dinâmica, mágica e real: "E o rio, o pequeno Pardinhas, que nascia em fiozinhos de nada, entre duas fragas, onde ia acabar? E o mar seria mesmo aquela poça gigante, sem princípio nem fim, com sal misturado, que bufava mais forte que cobra velha, de repente descoberta entre a folhagem?" (MOTA, 1999d, p. 127). O simbólico do texto literário repercute-se na realidade do leitor, cuja cosmovisão há de revestir-se de maior riqueza e profundidade. Essa mobilidade de tipo simultaneamente mimético e poético permite-nos notar a dimensão realista de António Mota, a sua vocação para isolar pormenores do mundo natural e doméstico que são reconstituídos e amplificados dentro de uma dimensão imaginativa e simbólica.

No discurso de António Mota há um conhecimento muito profundo de objetos, atos, rituais e trabalhos agrícolas. Esse conhecimento amplo de tudo o que se relaciona com a vida das comunidades rurais do Norte, traduzido em frases estruturalmente elegantes, com apurado sentido do ritmo e muito rica em vocabulário, concretiza-se numa sequência como esta, em que o narrador autodiegético descreve a confecção da broa: 
uvas. Pusemos a água dentro de um pote e acendemos o lume com a lenha que nessa manhã fomos arranjar. (...) Enquanto a água não fervia, minha mãe peneirou a farinha de milho para dentro da masseira. Nessa altura, a Rosa andava a correr os caminhos de Pardinhas à procura de bosta de vaca que apanhava para dentro de um alguidar partido. Com a bosta tapávamos a porta do forno. A água ficou morna, e minha mãe já punha junto da farinha peneirada o fermento, que se guardava numa malga. E começou a amassar. Juntou-lhe um punhado de sal, mais um bocado de água e continuou a mexer a massa que se agarrava às suas mãos avermelhadas. Já a lenha ardia no forno e, como não havia chaminé na cozinha, o fumo invadia a casa e fazianos tossir, sufocados, e chorar sem nenhuma vontade. Quando a massa levedou, e o forno aqueceu e foi varrido de brasas e cinzas, minha mãe pegou na tendedeira de madeira e começou a talhar as broas de pão. Apesar de estarmos habituados, ficávamos sempre de boca aberta a ver a nossa mãe a atirar a bola de massa ao ar que, depois de dar a volta completa, vinha estatelar-se dentro da tendedeira. Depois punha a broa numa redonda pá, polvilhada com farinha. E metia-a no forno. Repetia esses gestos cinco vezes, tantos como as broas de milho que cozíamos nas tardes de todos os sábados. (MOTA, 1999d, p. 53-55)

Nessa enciclopédia, encontramos casos tão curiosos para os leitores mais jovens como o da convivência ecológica entre o ser humano e a aranha. $\mathrm{O}$ homem, português e rural, luta, com a sua cultura ancestral, contra uma espécie, a mosca, que se pode reproduzir tanto a ponto de ser prejudicial para ele e para outra espécie de que obtém alimento (a vaca). A solução não passa pelo recurso à ciência química; é completamente natural, própria de quem vive ainda da observação das relações de interdependência entre as coisas da natureza:

Tinha ido pensar a parelha de vacas velhotas que pacatamente ruminavam na corte muito bem estrumada e emoldurada com um incontável número de teias de aranha que caíam do tecto e tapavam todos os buracos. Meu pai não deixava que as destruíssemos. Assim, ensinava ele, o mosquedo ficava preso na gosma das aranhas e não incomoda as vacas. Quando Deus criou o mundo, ainda bem que teve tempo de se lembrar das aranhas, bichos de muitas patas e de grande préstimo. (MOTA, 2002, p. 141-142)

Há também em António Mota uma compreensão muito exata da interioridade essencial de personagens como a criança que concretiza a ideia de Mal numa pessoa demonizada pelo grupo ${ }^{3}$, o homem que regressa à aldeia de

\footnotetext{
3 "Pensava também que o Chico da Juliana era o homem mais feio de toda a humanidade. E como vivia à beira do cemitério, esse velho baixinho falava com as almas penadas que em certas noites de lua nova saíam das campas e imitavam os gritos lancinantes das corujas” (MOTA, 2002, p. 47).
} 
origem após décadas de desterro na cidade ${ }^{4}$, a filha que sofre com a sorte e a solidão do pai $^{5}$ ou a mulher que a superstição popular transforma em bruxa ${ }^{6}$.

Livros como Os Sonhadores e Pardinhas são romances em que a poética do tempo se desdobra explicitamente numa poética do lugar: um enunciador convoca estágios sucessivos de um passado que é, antes de mais, uma tópica. Os lugares coordenam o tempo, dão-lhe intensidade, volume e peso; e é nesses lugares que as personagens, interagindo com outras entidades, constroem uma visão de si e dos outros.

A viagem física e a viagem mental (retrospectiva de viagens físicas) são atos de salvação: pelo intermédio delas, a personagem espera reconciliar-se consigo mesma e com a sua visão do mundo e dos outros. A ação de cada livro envolve por isso temas universais, figuras da inquietude humana: a identidade, a amizade, o amor, o desejo sexual, a comunicação interpessoal, a morte. Os destinatários desses livros sentem-se implicados no percurso das personagens mais jovens, que, como eles, debatem-se com problemas muito sérios de identidade pessoal. A obra Os Heróis do $6 .^{\circ} \mathrm{F}$ é, nesse aspecto, modelar: perda do outro como corpo e espírito, recuperação e luto do passado, ansiedade da procura amorosa, construção de identidades, encontros e desencontros: "O Miguel apareceu na escola. Não disse por onde andou, recusou-se a contar pormenores. Pareceu-me mais magro, mais triste, ou será impressão minha? À noite, minha mãe contou-me que ele foi ter a casa do pai a Lisboa, e este despachou-o no comboio. A mãe foi esperá-lo à estação de Campanhã, no Porto, e recambiou-o para casa dos avós" (MOTA, 1999 d, p. 123).

\footnotetext{
4 "Pouco incomodado com as cartas e o telefone, o senhor Joaquim levanta-se mal nasce o dia e põe-se a caminho do campo onde antes havia codessos, tojo e giestas, e agora parece um jardim, como diz minha mãe, sem uma única erva daninha e com dois espantalhos e muitas armadilhas para caçar toupeiras" (MOTA, 1999d, p. 108-109).

5 "Não posso precisar se foram mais de duas semanas. Mas foram, disso não tenho dúvidas, dias muito pouco divertidos os que se passaram em minha casa depois do avô se ter retirado de forma tão brusca. Nunca vi minha mãe tão abatida, nunca vi meu pai tão calado" (MOTA, 1999b, p. 69).

6 "Às vezes, sonhava que a Olivinha era uma bruxa horrorosa, com uma cara parecida com as dos morcegos, sem olhos e com asas de penas azuis" (MOTA, 2002, p. 9).
} 
No jogo constante e mortal que é a vida, acreditar na concretização do desejado constitui já uma redenção. Essa é a fórmula que rege a ação das personagens a que o narrador-personagem dedica mais atenção. $\mathrm{O}$ caos do dia a dia, as humilhações, as derrotas, as quebras psicológicas e existenciais são enunciados equilibradamente na economia de cada obra, sempre pautada pela estabilidade das categorias da narrativa (ação, espaço, tempo, personagens) e dos modos de representação (narração, descrição, diálogo). Mas dessa organização, dessa quase sempre simultaneidade entre o tempo do discurso e o tempo da história, não decorre uma escrita moralista ou beatamente edificante. A sobriedade e a íntima ternura que emergem da escrita de António Mota permitem uma representação enxuta e iluminante de mentalidades e costumes, virtudes e vícios, obsessões e traços sutis de caráter.

Se o discurso de António Mota se estrutura enquanto fala genuinamente humana, não surpreende que a sátira, o humor e a ironia nele participem como energia, extensão do corpo de um sujeito à procura de si. Essa passagem diz-nos, de modo perfeito, que, como manifestação pré-verbal e já como texto ou tonalidade textual, a sátira é um conflito orgânico entre a pulsão mais instintiva e desordenada e a racionalidade mais tensa e controlada; um conflito que não é meramente acessório e sim consubstancial ao humano: "O príncipe que cria porcos é solteiro". Na circunstância, a sátira também constitui um elemento de busca do outro, porque a gestualidade satírica em processamento é uma apresentação do eu ao outro: "E por hoje não me apetece estar aqui a escrever sobre o príncipe caladinho e maneta que cria porcos no palácio da Urgueira. Tenho mais que fazer" (MOTA, 1999d, p. 101), afirma catarticamente Manuela, a narradora-protagonista de Os Heróis do $6 .^{\circ} \mathrm{F}$, referindo-se ao noivo da sua mãe.

Prova-se que a sátira e o satírico não se reduzem necessariamente ao binômio ressentimento e agressão; e insinua-se que, mesmo se são redutíveis a 
esse ponto de vista, a sátira e o satírico dizem-nos que o ser humano vive a sua contingência. Sigmund Freud vê no ato humorístico um mecanismo psíquico de defesa perante as adversidades colocadas ao sujeito, veículo revelador de exasperação ou agressividade; e Jean Cohen define assim a dualidade inerente ao cômico, particularmente visível nos excertos transcritos, em que o burlesco aciona a desfiguração do referente:

Le sentiment du comique exprimé par le rire est la gaieté ou l'euphorie provoquée par le brusque retour du sujet de l'émotion à l'indifférence ou aporie, lui-même induit par une contradiction axiologique interne, c'est-à-dire par la conjonction au sein d'une même unité de deux significations pathétiques opposées qui se neutralisent réciproquement (COHEN, 1985, p. 57)

A essas definições, imprescindíveis para compreendermos o que é a essência do satírico e de procedimentos mentais e textuais contíguos, há que acrescentar o que nenhuma antropologia da sátira deverá ignorar: como processo de demonização do outro, a sátira é muitas vezes descoberta que convoca o outro, não um simples ato de desprezo e hostilidade. Precisamente: Manuela encontra na sátira uma comunhão consigo mesma e com a palavra enquanto objeto de prazer, mas também uma dialética de questionamento da sua subjetividade.

A narrativa de António Mota perspectiva a vocação da criança para acolher com deslumbramento os seres dos vários reinos - animal, humanoanimal, mineral e vegetal -, metamorfoseando-os e recobrindo-os de novos significados. Esta sequência é paradigmática da propensão dos mais novos para o estabelecimento de uma comunicação vivificante entre elementos de campos não raro inconciliáveis: “Os homens, por mais pequeninos e insignificantes, por onde passam deixam sempre marcas. E o Joaquim estava presente, transformado

\footnotetext{
7 "O sentimento do cômico expresso pelo riso é a alegria ou euforia provocada pelo retorno brusco do sujeito da emoção à indiferença ou aporia, induzido por uma contradição axiológica interna, isto é, pela conjunção, dentro de uma mesma unidade, de dois significados patéticos opostos que se neutralizam reciprocamente".
} 
num melro, na varanda da nossa casa" (MOTA, 1999d, p. 191). A singularidade do corpulento Joaquim que falava com os pássaros é transferida para o melro que ele deixa às crianças como pedido de remissão pela sua partida repentina e misteriosa, e como memória da sua presença na casa:

Por isso o bicho era um abastado na mantença, pouco invejoso com a passarada que o vinha visitar, surripiando-lhe do comedoiro o pão e as minhocas inteiras que a Rosa se entretinha a descobrir na terra húmida dos lameiros (MOTA, 1999d, p. 191).

No olhar e nos atos que garantem a "dignidade do ser", na formulação muito sugestiva de Sophia de Mello Breyner, há já um sentido muito profundo da existência, a pertença a um espaço ontológico original:

A cabra ali estava à nossa frente, com uma cordinha enlaçada num corno e na metade outro; tinha um olhar perdido e lentamente ruminava uma tristeza que logo fez mossa no meu coração com nove anos de vida. Pobre da bicha, ali assim presa, sem conhecer ninguém, se calhar com o corpo magoado de muita pancada ter apanhado, só pele e osso de tanta fome passar, e prenha (MOTA, 2002, p. 32-33).

Toda essa ambiência, concentrada num incipit como "Naquele tempo, todas as casas do Souto fumegavam logo de manhã" (MOTA, 2002, p. 7), situa de imediato os leitores - adultos e crianças - no universo das histórias tradicionais. Mas o "era uma vez" implícito naquela fórmula de abertura é apenas o ontem de pais e avós empíricos que não só corporizam como também dão voz (nas sínteses com que contam o passado aos filhos e netos) a algumas das personagens das obras de António Mota; voz, física e espiritualmente, pessoal, não, à maneira da maioria dos contos tradicionais e populares, voz impessoal.

A escrita de António Mota é herdeira de um mundo naturalístico e de uma vocalidade literária que a narrativa acolhe como tributo e húmus que propicia o texto lavrado no papel: 
Mas do que ele mais gosta na vida é ver-se rodeado de gente nova, ver os rapazes sentados à sua volta para ouvir as histórias que só ele sabe contar com aquela fala meiga, pousada. Ele a falar devagarinho e nós a vermos logo ali à nossa frente os castelos assombrados, reis, fadas, bruxas e bichos esquisitos de cinquenta patas, vinte e nove rabos, cento e cinquenta olhos e dezanove cabeças agarradas ao mesmo pescoço, que havia no tempo em que os animais falavam. Histórias tão compridas e cheias de peripécias, cada qual a mais intrigante e misteriosa... (MOTA, 1998b, p. 14$15)$.

O imaginário e o processo concretizados nessas narrativas estabelecem-se como heterotopia, vocábulo que encerra o essencial da Literatura: construção e busca de lugares que se sucedem interminavelmente. Lugares que o corpo, por necessidade psicobiológica, quer fixar, reclamando por isso a maternidade do corpo da palavra oral: "E eu, deitado na minha cama, puxava o lençol para cima da cabeça, ouvia os passos da minha mãe sobre o soalho e depois voltava a adormecer embalado pelas cantigas que ela sussurrava ao meu irmão (...)" (MOTA, 2002, p. 9).

O jovem leitor não é por certo indiferente ao significado autobiográfico e cosmogónico daquelas histórias fragmentárias e mínimas: descrição de episódios da vida de um autor e explicação da origem e funcionamento do mundo (o físico, material, e, simultaneamente, o imaginário, que se concretiza não só no plano da abstração e do simbólico, mas também no da imanência). O próprio autor empírico, de resto, num depoimento sobre a origem e o significado da sua atividade de escritor, nota a existência de um cruzamento entre o texto do livro e o texto da realidade:

Para ser sincero, e por muito que isto destoe, o grande culpado foi certamente o velho Adrianinho da minha aldeia, que muito gostava de contar histórias esquisitíssimas, onde havia quase sempre um eremita, que comia ervas e mamava nas tetas das lobas um leite mais saboroso que o das cabras fartas (MOTA, 1998a, p. 26).

Realidade, ficção, realidade da ficção, ficção do real: a palavra descreve, narra e, ao mesmo tempo, cria universos que tanto desvendam como geram sentidos e enigmas; a palavra concretiza a fusão do real e do fantástico numa 
unidade que é a verdade mais autêntica. No circuito incontrolável da realidade com ficção e da ficção autobiográfica com elementos de cosmogonia há só um denominador comum: a multiplicação de textos, percursos, imagens e significados:

Um dia o Adrianinho desapareceu da aldeia e foi morrer nas fragas do Marão. Algum tempo depois vi-lhe os ossos metidos num saco de serapilheira e logo me pus a magicar uma história para aquele eremita que não teve a sorte de encontrar uma loba que o deixasse provar do tal leite que tinha a força da terra" (MOTA, 1998a, p. 26).

Em última análise, preconiza-se que não há ficção sem autobiografia nem realidade (autobiografia) sem ficção.

Nestes universos de palavras há uma ordem figural: o escritor e o contador de histórias (este, no texto de António Mota, é também escritor porque algumas das suas palavras são escritas pelo escritor). O professor Miranda de $A$ Aldeia das Flores resume assim metaforicamente o ofício de escritor:

- Olha, escrever uma história é quase como pegar num arado. Neste caso é a caneta. Escrever é lavrar um campo que não está cultivado. Lavra-se, grada-se, semeia-se, sacha-se, arrenda-se, rega-se. E lentamente a história vai ficando com forma, vai crescendo, amadurecendo. Num campo, depois de o milho estar maduro é que se corta e se recolhe (MOTA, 1999a, p. 23).

Escrever é lavrar, lavrar é escrever: eis, também, como se define metalinguisticamente o estilo verbal e frásico de António Mota. A valorização da palavra é acentuação da textualidade enquanto campo de pensamento cognitivo, estético e ético.

O leitor infantil e o juvenil (também o adulto), principalmente se já conhece algum romance de António Mota, quer prosseguir ou retomar a leitura, acompanhar os episódios de que cada obra se constitui. Parece-nos que isso acontece porque a narrativa desse escritor convida a "ler o mundo real como se fosse uma obra de ficção" (ECO, 1994, p. 123): não só por desencadear a 
organização e compreensão do enredo interminável que é a vida, tornando-a, por um efeito de distanciamento, mais confortável do que o real, mas também por garantir uma irradiação de eternidade sobre a finitude de tudo. O tempo e o espaço da leitura criam esse cosmos que recobre a temporalidade em que cada leitor é agente, vítima e testemunha.

\section{0 caráter psicológico nas diegeses}

Demonstrar que o nosso tempo é o resultado de um longo processo em que à decifração de enigmas sobrevêm novos problemas, às respostas novas perguntas, aos atos justos novos enganos e omissões significa perceber que só seremos livres e responsáveis na verdadeira acepção dos termos se nos descobrirmos livres e responsáveis. Não é por acaso que o narrador autodiegético inscreve a sua interpretação dos paradigmas do Bem e do Mal num processo contínuo de reversibilidades. A dramaticidade da diegese reside em grande parte nessa contínua avaliação do sistema de valores ético-morais. A personagem mais comum destaca-se enquanto herói, mas também se recorta a sua faceta anti-heróica. $\mathrm{Na}$ extensa galeria de personagens e costumes que os livros de António Mota nos apresentam, há por isso figuras e episódios que nos seduzem pela densidade dos conflitos psicológicos e das soluções concretas.

Percebe-se que a cada intriga subjaz uma axiologia, não um moralismo. $\mathrm{O}$ jovem Zé Carlos do livro dentro do livro que é o romance Os Sonhadores, vítima na sua aldeia de incompreensões, equívocos e preconceitos, parte para a cidade do Porto com a consciência de que "O homem é o lobo do homem": “Eu estava farto de ser tratado como um rafeiro. Cheguei a pensar que os cães tinham mais sorte que eu. Ninguém notava, porque eu disfarçava como podia, mas eu trazia dentro de mim uma tristeza muito grande, parecia-me que não tinha lugar neste mundo" (MOTA, 1999e, p. 132). Com as novas e intensas 
experiências, não deixará de acreditar naquela proposição de Thomas Hobbes, mas aprenderá que o Bem e o Mal se encadeiam, cruzam e confundem; que, acima de tudo, são um efeito da perspectiva de quem ajuíza. Quando Gilinho pergunta se ele está ali em férias, Zé Carlos responde que ainda não beneficia dessa regalia:

Tive de inventar uma desculpa. Disse que tinha recebido uma carta da minha mãe a dizer-me que o meu avô estava muito malzinho, e que ele gostava de me ver antes de se apagar. Eu chorava mesmo a sério e o senhor director deu-me três dias de folga (MOTA, 1999e, p. 145).

A mentira (“- Mas tu já não tens nenhum avô. E se ele descobre?”) é, no caso, um modo de dizer a verdade, a estabilização de um desajustamento social e existencial:

- Não vai descobrir. Ele sabe lá onde fica o Plameiro! Eu não fugi, ele é que me deu três dias de folga. A gente tem de ter os olhos abertos, Gilinho. Olha que a cidade tem muito que se lhe diga! E no Hotel então é que se aprendem coisas. Sabes o que é que fazem aos mandaretes que adormecem em pé? Dão-lhes beliscões e caneladas quando ninguém está a ver. E eles engolem em seco, e ficam quietinhos e aprumados... (MOTA, 1999e, p. 146).

A complexidade do real revela-se quando somos confrontados com preconceitos e ideias feitas que eram em nós apenas automatismos. Essa é a lição mais geral de Fora de Serviço, que, num cenário citadino e investindo numa temática diferente da tratada nos livros anteriores, narra um caso exemplar: uma mãe, perante o egoísmo do marido e dos filhos, que não a ajudam nas tarefas domésticas, decide regressar à sua aldeia. Essa situação levaos a assumir que o seu comportamento estava errado; por isso, vão buscá-la e, a partir daí, começam a dividir o trabalho. A procura e a exposição da verdade do mundo pela verdade do narrado concentram-se ora na fala de todos os dias das personagens, ora na voz do narrador, cuja focalização nunca é excessiva nem

\footnotetext{
${ }^{8}$ Recorde-se que aquela frase, também na obra Sobre o Cidadão (1642), culmina nesta outra máxima,
} igualmente importante, embora menos divulgada: "Guerra de todos contra todos". 
monótona. Essa alternância constante entre a visão do narrador e o diálogo anima o texto e suscita o interesse do leitor, que assim vai satisfazendo a sua curiosidade e a sua necessidade de histórias.

O discurso de cada personagem, atravessado por marcas dialetais e socioletais, é, pelo seu realismo, muito sugestivo. Introduz o leitor em mundos quase completamente desconhecidos ou esquecidos como os da pobreza, da consequente falta de instrução escolar e seus efeitos existenciais:

- Quem dera! No meu tempo não era assim! Quando era criança, ninguém era obrigado a ir à escola. A maior parte dos rapazes não ia e as raparigas muito menos. Naquele tempo só os filhos das pessoas com posses frequentavam a escola e continuavam os estudos. Os filhos dos pobres iam para os seminários, mas isso acontecia de tempos a tempos. É por isso que quase todos os padres são filhos de gente humilde. Eu frequentei a escola durante um ano, com muitas faltas pelo meio... O professor também não ajudava muito, usava tamancos e, quando se arreliava, tiravaos dos pés para fazer pontaria às carteiras... Deixei a escola e fui servir para casa de um lavrador. Guardava-lhe o gado, cortava erva, tapava as poças e deitava água aos lameiros. Em troca davam-me a comida e a roupa. Tempos ruins, amigo Jorge, tempos ruins... A vós parecem-vos histórias, mas não, era mesmo assim. (MOTA, 1998b, p. 16)

A mensagem de construção de uma pessoa livre e responsável não se perde na interpelação ao leitor. O texto é narrado na primeira pessoa, às vezes na forma de diário", por uma voz jovem: "meu coração com nove anos de idade" (MOTA, 2002, p. 32). Mas também há vozes senhoris que rememoram subjetivamente o seu passado mais longínquo e comunicam as coordenadas e vivências do seu eu infantil por meio da focalização interna: "Ficava assim combinado entre todos que os dias de feira faziam sempre dores de cabeça ao meu pai. E ponto final na conversa, os telhados inventaram-se para encobrir os sonhos e as misérias, e as portas e janelas existem para mostrar as alegrias e as tristezas dos que lá moram” (MOTA, 2002, p. 32). Em passagens como a transcrita, o narrador-personagem, que se quer interventivo e reflexivo, revela um prazer vital por se descobrir construtor da sua identidade.

\footnotetext{
9 "Começo a escrever este diário na tarde do último dia em que fui pela última vez à escola" (MOTA, 1998b, p. 7).
} 
A vastidão do mundo implica uma visão ilimitada sobre a vida. Assumir esse pressuposto evita que qualquer pedagogia exercida pelo texto incorra na linearidade. Em Fora de Serviço, a complementaridade de funções de homens e mulheres surge como tema que, não sem equívocos e sofrimento, uma família necessita discutir e resolver, dentro dos parâmetros da organização social e familiar dos nossos dias. No final, após um processo de aprendizagem abrupto, mas produtivo, desencadeado pela saída temporária de casa da mãe, dá-se a harmonização dos elementos: o pai e os dois filhos compreendem que devem participar ativamente na realização das tarefas domésticas. Essa mudança de valores masculinos evolui, no espaço da leitura, para uma mensagem de renascimento do social e do humano. Num texto em que se visa explicitamente uma pragmática de consciencialização das crianças e dos adolescentes para o que deverá ser a cooperação entre os membros do microcosmos doméstico, a significação profunda não é afetada. Há uma doutrinação, mas não existe uma perspectiva primária e artificial; o valor pedagógico do discurso vem da dimensão de testemunho do narrador de primeira pessoa, não de programas destinados a impor uma verdade.

Com esses livros, que suscitam uma adesão especulativa, ética e estética, o jovem leitor verifica uma ideia porventura já nele muito interiorizada: a Literatura é sublime, a vida (sem histórias em palavras) vulgar. Em contacto com a ficção literária, as histórias da vida ganham densidade. A verdade da existência é instruída pela verdade da ficção.

Pardinhas, como muitos outros livros de António Mota, é a sublimação de uma memória que só o discurso ficcional permite (re)constituir; uma memória a que não é alheio um sentido de dispersão figurado na sucessão de episódios, mas, acima de tudo, uma memória que se nos apresenta enquanto lugar de plenitude. 
Nesse espaço de rememoração, povoado por personagens comuns que se transfiguram miticamente, o contexto mais local eleva-se a lugar universal. A singularidade de Joaquim Batata - "Alto, corpulento, com uma boina espanhola, suja e esburacada, a cobrir-lhe a cabeça volumosa, parece que ainda o vejo a aparecer em Pardinhas" (MOTA, 1999d, p. 119) - resulta de uma síntese de valores humanistas: despojamento de bens materiais, simplicidade, dedicação ao outro. O pai do narrador de segundo nível também representa uma característica essencial do humano: o espírito de sacrifício, a capacidade de perseguir um objetivo justo, mas, por vezes, impraticável. Zé constrói uma casa e perde-se por ela: emigra para o Brasil em busca de uma solução e aí desaparece. A família não pode evitar o rompimento da unidade original: a casa é vendida, a irmã e a mãe ficam na aldeia, de novo na condição de inquilinas ${ }^{10}$, e os dois filhos seguem para o Porto, onde se dedicarão a "Trabalhos diferentes, e em sítios diferentes" (MOTA, 1999d, p. 252).

A viagem de comboio que os levará à cidade é metáfora da viagem pela vida; numa e noutra misturam-se a angústia, o medo, a alegria e a coragem. A família enquanto núcleo desfaz-se, mas os seus membros permanecem ligados como obreiros de uma nova saga: "Contentes e baralhados, receosos de nos perdermos, mas com uma vontade enorme de vencer todos os obstáculos, sentámo-nos nos bancos de pau da carruagem, e rimo-nos quando o comboio apitou, deu um safanão e começou a andar" (MOTA, 1999d, p. 253).

Mas não se deduza dessa esquematização a ideia de que os desenlaces das histórias de António Mota são idealizados e, por isso, romanticamente eufóricos (à maneira de um Júlio Dinis). Essa poética tem subjacente uma concepção de literatura como comunicação que quer contribuir para a construção da

\footnotetext{
10 "Quando se convenceu que os sonhos de meu pai eram espelhos partidos aos pedacinhos, vendeu a casa ao Antoninho Foguete. Pagou a dívida, os juros, e os juros dos juros, e ainda ficou com algum dinheiro. O mais difícil foi convencer D. Sancha a alugar-lhe uma horta com bastante água, e a ficar na casa como inquilina, pagando uma renda anual" (MOTA, 1999d, p. 249).
} 
integridade ontológica e ética de cada leitor. Se forem processos complementares de humanização, a vida e a escrita da vida revestir-se-ão de mais espessura e de sentidos que continuamente se multiplicam e questionam. Daí haver uma mensagem que atravessa todas estas obras: as relações interpessoais e os obstáculos são muitas vezes o inferno em que nos desgastamos; contudo, a procura de uma resolução e o encontro com o outro constituem também uma benção e uma redenção.

Por tudo isto, numa obra em que cada personagem incorpora uma temática do humano, o mais local e regional (adjetivos muito ao gosto de alguns leitores precipitados de António Mota) compatibiliza-se com o humanismo mais universalista. Obviamente, sugere-se que cada personagem só pode ser compreendida no meio em que se movimenta; porém, essas figuras transcendem sempre o seu pequeno universo histórico, social e moral, impondo-se como signos das capacidades do humano, ora pelo estoicismo e pela resistência à pobreza e ao obscurantismo, ora pela coragem que significa sair da terra natal em busca de um lugar no mundo. Duas respostas bem diferentes a que se associa o mesmo sinal positivo de heroicidade na procura de um campo ideal em que a vida possa ser vivida em dignidade e intensidade.

Nesses livros encontramos uma parte muito considerável do devir do ser português. Isto só é possível porque António Mota representa o campo, mas não o idealiza. É a partir do ponto de vista das personagens que ele constrói a narrativa, não a partir de um narrador omnisciente preocupado em veicular uma imagem preconcebida e dulcificada do Norte de Portugal.

Esse procedimento nada tem a ver com as mi(s)tificações que presidiam às novelas e aos romances para a infância e a juventude produzidos à luz da ideologia do Estado Novo. Ganham com esta escrita a Literatura portuguesa, a memória portuguesa e os jovens leitores portugueses (e não só), que não podem 
viver bem com a verdade única que lhes apresenta um mundo reduzido e redutor; ganham a vida portuguesa e o ser português em Portugal e no mundo.

\section{Referências}

COHEN, Jean. "Comique et poétique". Poétique. Paris, n. ${ }^{\circ}$ 61, Éditions du Seuil, p. 41-61, février 1985.

ECO, Umberto. Seis passeios pelos bosques da fição. Trad. de Hildegard Feist. São Paulo: Companhia das Letras, 1994.

GENETTE, Gerard. Discurso da narrativa. Tradução de Fernando Cabral Martins. Lisboa: Vega, s.d.

MOTA, António. "António Mota". In: II ENCONTRO COM A ADOLESCÊNCIA - A Escrita e a Leitura. Caminhos com Futuro, 21-22 / 28-29 de Abril de 1995. Anais..., Porto: Edinter, 1998a, p. 26-28.

. O rapaz de Louredo. Ilustrações de Pedro Monteiro. 4. ${ }^{\mathrm{a}}$ ed. Porto: Edinter, 1998b (1. ${ }^{\mathrm{a}}$ ed., 1985).

. A aldeia das flores. Ilustrações de Luísa Brandão. 6. ${ }^{\mathrm{a}}$ ed. Rio Tinto: Asa, 1999a (1. ${ }^{\mathrm{a}}$ ed., 1986).

. A casa das bengalas. Ilustrações de Bayard Christ. 3. ${ }^{\mathrm{a}}$ ed. Porto: Ambar, 1999b (1. ${ }^{\mathrm{a}}$ ed., 1995).

. A terra do anjo azul. 4. ${ }^{\mathrm{a}}$ ed. Vila Nova de Gaia: Edições Gailivro, 2002 (1. ${ }^{\mathrm{a}}$ ed., 2002).

. Fora de serviço. Ilustrações de Carlos Marques. Porto: Ambar, 1999c.

. Os heróis do $6 .^{\circ}$ F. Ilustrações de Bayard Christ. 3. ${ }^{a}$ ed. Porto: Ambar, 1999d (1. ${ }^{\text {a }}$ ed., 1996).

. Os sonhadores. Ilustrações de Bayard Christ. 4. ${ }^{\mathrm{a}}$ ed. Porto: Edinter, 1999e (1. ${ }^{\mathrm{a}}$ ed., 1991).

. Pardinhas. 2. ${ }^{\mathrm{a}}$ ed. Vila Nova de Gaia: Edições Gailivro, 2005 (1. ${ }^{\mathrm{a}}$ ed., 2005).

NOGUEIRA, Carlos. "Uma forma breve esquecida: a praga da tradição oral portuguesa". Trabalhos de Antropologia e Etnologia. Porto, Sociedade Portuguesa de Antropologia e Etnologia, vol. 47 (1-4), p. 123-31, 2007. 